\title{
Modelling the Outcome of Credit Shocks in Small Open Economy ${ }^{1}$
}

Vytautas Snieška, Prof. Dr.

Department of Economics and International Trade Kaunas University of Technology, Lithuania Email: vytautas.snieska@ktu.It

\section{Vitalija Venckuvienè, Dr.}

Department of Economics and International Trade Kaunas University of Technology, Lithuania

Email: vitalija.venckuviene@ktu.It

Gitana Valodkienè, Dr.

Department of Economics and International Trade Kaunas University of Technology, Lithuania

Email: gitana.valodkiene@ktu.lt

Rūta Masteikienè, Dr.

Department of Economics and International Trade Kaunas University of Technology, Lithuania Email: ruta.masteikiene@ktu.It

\section{Doi:10.5901/mjss.2013.v4n9p619}

\section{Abstract}

The literature analysis implicates that there are various forecasting models which were established in order to foresee the fluctuation of economy. Although the recent economic crisis has shown that large proportion of these models appeared to be misguiding. Mainly due to one reason - most models did not incorporate the external reasons of fluctuations of financial sector. While the research studies show that the risks that were engulfed by financial sector were one of the main drivers for the 20072008 recessions. Moreover the use of dynamic and stochastic general equilibrium models (here and after DSGE) for the economies modelling purpose seems to be not adequate for forecasting crisis of such types. Thus the need of the model which incorporates the core financial sector performance factors is obvious. Therefore the main aim of this paper is to determine the factors for modelling the small and open economy's cycles consequences. We try to explain what the outcomes of credit shocks are in small and open economy, and how it responds on the industry based data. It employs methods of analysis and systematization of literature and documents, as well as multifactorial statistical data analysis.

Keywords: small and open economy, credit shocks, business cycles.

\section{Introduction}

Enormous quantity of research dealing with the factors of credit shocks, evaluating its outcomes and effects on economies or forecasting future cycle's show, that modelling in economic research field is still of particular relevance. The present paper aims to provide answers to such research questions like: how credit shocks affects the small and open economy? And what are the essential factors should be included in the modelling future fluctuations in economy and how? Following these questions, the paper explores the main characteristics of recent recession and explains this phenomenon in statistical data analysis.

Therefore the main aim of this paper is to determine the factors for the modelling the small and open economy's cycles consequences. The article will explain what the outcomes of credit shocks are in small and open economy. The

${ }^{1}$ This research is funded by a grant (No. IEP-01/2012) from the Research Council of Lithuania. 
objectives of paper are as follows:

1. To reveal theoretical aspects of credit shocks and its outcomes;

2. To determine the core techniques in modelling outcomes of credit shock;

3. To explore how the credit shocks are reflected in statistical data.

The methods employed in the paper are as follows: analysis and systematization of literature and documents, as well as multifactorial statistical data analysis.

The second section of paper presents the theoretical aspect of credit shocks modelling and their main features in small open economy. Third part of this paper presents the main results of statistical data analysis and finally the paper ends with concluding remarks.

\section{The theoretical issues and the methodology}

\subsection{Credit shocks and its impact on small and open economy}

Literature review indicates that the monetary policy is characterized by inertia and persistent credit shocks (Carrillo, F'eve \& Matheron, 2007). Credit shock in macro-economic research papers is characterized as sharp reduction in access for loans or increase of costs of getting loans. Few more terms are used - the credit crunch and credit boom sometimes used as synonymous to credit shocks in economic literature, what is not correct.

Moreover there are many recent research papers dealing with the causes and effects of credit shocks in the light of 2007-2008 recession (Fornari \& Stracca, 2011; Pesaran \& Xu, 2013; Bedock \& Stevanovic, 2012; Maredza \& Ikhide, 2013). According to Pesaran and Xu (2013) findings "The effects of the credit shock are found to be very persistent and profound, consistent with empirical studies on the output effects of financial crises, which suggest that recessions associated with financial crisis have been much longer lasting than recessions associated with other shocks" (Pesaran \& $X u, 2013)$. Ivashina and Scharfstein (2010) indicate that credit peak was the starting point for the "meltdown of subprime mortgages", which in turns influenced the panic in financial sector and had impact to other closely related sectors like real estate.

There are many factors for the formation of credit shocks. It is evident that they are caused by both supply side and demand side factors. One of the main supply side factors is the interest rate for the borrowing. On the opposite side the demand for the credits from the firms and individuals which in terms are sensitive and depend on information in mass media about the increasing price of asset and vice versa.

Figure 1 present both the factors of credit demand and supply shocks
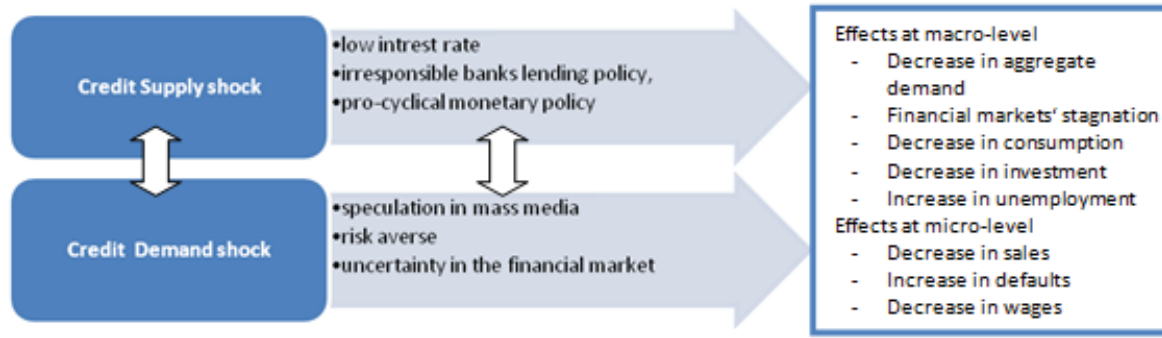

Figure 1. Two sides of credit shocks

Irresponsible banking sector lending policies involve both micro and macro economic nuances. At micro level they are associated with issuing loans to an individual in easy manner with high level of uncertainty whether he or she will be able to give it back with some determined interest rate in the future.

At macro-economic point of view irresponsible banking sector lending policy is characterized by a complex features such as the performance in parallel markets (for instance, real estate market), huge competition in financial market and the borrowing costs (interest rates).

When summarising the fig. 1 , the particular attention should be paid on the credit supply shocks. When analyzing economic literature once can notice that it is very difficult to indentify differences between credit supply and credit demand shocks. According to Abildgren (2011) credit-supply shocks "can affect the ability and willingness of monetary 
and financial institutions to supply credit to non-financial firms and households" (Abildgren, 2011), and more over this associates with decline in credit demand. These processes together have a "chain reaction" in many economic spheres.

Moreover credit itself has a "virtual" money feature. It means that banks by issuing credits, make credit bubbles in the economy, and when the "money cloud" spreads, the real situation appears, which in terms make negative influence on the demand of credit. The effect of credit supply and credit demand shocks have micro and macro sides (see Fig. 1): decrease in aggregate demand, uncertainty in markets, countries' specific factors (like economic structure), inflexibility of financial markets and many others.

Fluctuations in financial markets are associated with contraction in many economic activities (Gilchrist \& Zakrajšek, 2012). In addition Setterfield (2011) argue that "exhaustion of a financialized growth process" was the core trigger for the recent recession. Simulations made by Gilchrist and Zakrajšek (2012) indicate that an "intensification of financial stresses implies a sharp widening of credit spreads, a significant slowdown in economic activity, a decline in short-term interest rates, and a persistent disinflation." (Gilchrist \& Zakrajšek, 2012). The research evidence of Bedock and Stevanovic (2012) indicated that credit shocks have impact on price indicators, leading indicators and credit spreads.

Financial markets are much related and it is no doubt that changes in one country's financial market affect performance of others too. The influence of external financial markets on the credit shocks in domestic market was emphasised by research results of Bedock and Stevanovic (2012). Having in mind that financial market are very close related and affected by globalization processes, this possible could be named as a main factor for long recovery processes.

Domination of negative aspects of credit shocks in economic literature implicates that they affect the whole economy in terms of overall slowdown (Almeida, Campello, Laranjeira and Weisbenner, 2011; Bedock and Stevanovic, 2012; Gilchrist \& Zakrajšek, 2012). Bedock and Stevanovic (2012) found the relation between global credit shocks and economic slowdown in terms of interest rates growth and decline of credit related indicators (for instance in Canada) (Bedock \& Stevanovic, 2012). In addition Greenstone and Mas (2012) and Chodorow-Reich (2012) argued that huge negative effect was for employment rate. According to Greenstone and Mas (2012) „Upper bound estimates suggest that the 2007-2009 decline in small business lending accounted for up to $20 \%$ of the decline in employment in firms with less than 20 employees, $16 \%$ of the total employment loss, and $30 \%$ of the decline in inflation adjusted aggregate wages during this period". Bedock and Stevanovic (2012) suggest that financial crisis, which rooted in credit market performance, affected closely related markets like real estate, especial indicators of employment, revenue growth and the huge amount of defaults rates. Moreover Almeida et al. (2011) provide empirical evidences that 2007 crisis and appearance of long term debt in a particular firm affect investment negatively, and reached approximately one third pre crisis investments level.

Despite the negative nuances of credit shock some researches indicate few positive things related to credit shocks. For instance, Pesaran and Xu (2013) argue that "A positive credit shock, defined as a rise in the loan to deposit ratio, increases output, consumption, hours and productivity, and reduces the spread between loan and deposit rates."

Still we argue that it is not appropriate to distinguish negative or positive outcomes, the holistic view of economy performance is the most important one. The complexity of the 2007-2009 worldwide financial crisis disclosed that this phenomenon integrates many aspects of macroeconomics. Health of economy consists of many components/substitutes and most important refer to macro prudence in monetary policy.

To sum up, literature review indicate that due to financial crisis there was conspicuous decrease in many scopes of economic activities; increase of unemployment, decrease of consumption, which is the main engine of economy and thus the harm was so deep which caused the recession which still has effect of long an slow recovery of economies.

\subsection{Modelling credit shocks}

This section is intended to present briefly the techniques that are used in analyzing and forecasting financial fluctuations. There are plenty of modelling techniques covering both qualitative approaches relaying on experts' opinions, and quantitative approaches starting from simple ones time series analysis, regression analysis, and moving to more sophisticated modelling, vector-autoregressive models (VAR), dynamic stochastic general equilibrium models (DSGE model). Right after the 2007-2008 recession the critique of economic forecasting models appeared in the mass media as well as in research platform. Huge critique wave was addressed to the use of DSGE models (Garcia, 2011, Wickens, 2012).

Models are usually based on some theory strands. For instance, DSGE models incorporate new-neo Keynesian principles, VAR model is mainly based on Bayesian theory. Although they were very popular in research discourse, but 
still they did not anticipated such deep recession and long recovery.

Nevertheless Setterfield (2011) stresses that two of theory strands - post-Keynesian (PK) Economics and Regulation Theory (RT) - were "successful in anticipating the crisis as resulting from the exhaustion of a financialized growth process." (Setterfield, 2011). Despite the PK and RT theories differs in terms of "income generating process; and the nature of aggregate fluctuations in economic activity." (Setterfield, 2011), the similarities are in terms of emphasis of institutionalism and "common conception of capitalist growth as unsteady- i.e., subject to aggregate fluctuations." (Setterfield, 2011).

Among the most popular techniques for forecasting future economics fluctuations are as follows: ARIMA, VAR and DSGE. Time series analysis - Autoregressive Integrated Moving Average Process (ARIMA) structure as follows: autoregression (AR) process; Integration process (I); and Moving average (MA) procedure.

Vector autoregression (VAR) or factor augmented VAR (FAVAR) methods are popular in forecasting economics fluctuations as well. Bedock and Stevanovic (2012) suggest factor-augmented VARMA (FAVARMA) model incorporating moving average components. VAR is simple model due to respect of linear equations "where each of the endogenous variables is explained as a linear function of its own lagged values and the lagged values of all the other variables in the system" (Abildgren, 2011).

More modern technique and more sophisticated than previously mentioned so called Dynamic Stochastic general Equilibrium has its roots in the Chicago school and is based on "new neo-Keynesian approach" (Garcia, 2011). Recent research scope is plenty of research papers dealing with DSGE models; especially this technique is popular in banking sector. DSGE models were developed and widely adapted in various countries institutions during 1983-2008. Prominent central banks have their own DSGE models (European central bank Area wide model (AWM) and New Area-Wide Model (NAWM); Sveriges Riksbank RAMSIS I and RAMSIS II; and etc.).

Numerous studies have emphasized that while DSGE approach has significant advantages in comparison with other simpler models (eg, time series), it is not appropriate in all circumstances, i.e. DSGE models (as well as other simpler models) accurately predicts stable economic growth (Garcia, 2011; Wickens, 2012), but are unable to predict shocks of qualitative origins.

The detailed research of various DSGE models and comparison between parameters and filters was prepared by Wieland et al. (2012). The authors conclude with the prepositions for future research: to create DSGE models "with more realistic treatments of banking and financial risks", to pay more attention on "imperfect information, learning and heterogeneous beliefs", and to allow models "for deviations from the basic microeconomic assumption of rational optimizing behaviour by households and firms" (Wieland et al., 2012).

To sum up the theoretical aspect of credit shocks, the emphasis of financial market turmoil is of particular importance, because banks like financial intermediates have unconditional effect in money creation, thus the macroeconomic modelling should be extremely influenced by integrating this effect in modelling possible fluctuations in economy.

After the 2007-08 crisis the research platform was full of suggestions that the econometric modelling should include the financial sector related aspects (Pesaran \& Xu, 2013; Setterfield, 2011; Garcia, 2011; Wickens, 2012). For instances Pesaran and Xu (2013) deals with the new modelling approach integrating the aspects of financial intermediation and both households' and banks' defaults (Pesaran, Xu, 2013).

To summarize the analysis of macroeconomic forecasting models one is obvious - mainly they are based on past time data series. And so the analysis is based on the past performance of economics. That is that shocks should be the outcome of the past behaviour of analysed data, what is often not, because these data interact as processes which is impossible to describe using continuous functions. The other shortcoming of econometric modelling is an assumption, that forecasts are based on assumption "all other factors are stable".

\subsection{Research Methodology}

Before presenting the research methodology it should be mentioned, that the research presented in this paper is prepared under Lithuania Institutional Economics Research Program "The Challenges of Lithuanian Economy Long-term Competitiveness" and it is the first step of the modelling. Thus the method used in this paper is only one out of the comprehensive methodology of the whole project - to conduct statistical data analysis, and to construct the model which fits Lithuanian context.

This section intends to describe methodological approach towards modelling credit shocks in small and open economy. The research findings so far in this paper suggests, that when modelling credits shocks the financial markets 
fluctuations are extremely important. Credit spreads is popular indicator in exploring credit shocks (Bedock \& Stevanovic, 2012; Fornari \& Stracca, 2011; Gilchrist \& Zakrajšek, 2012). For instance, Pesaran and Xu (2013) in their research paper found that credit shocks are related to reduction in interest rate spread index. Other popular indicator in analysing credit shocks is CDS (credit default swaps). According to Chenyu Shany (2012) "Credit default swaps (CDS) are derivative contracts referencing debt repayments". The growth of the CDS market inspired huge interest in research papers on this indicator especially after credit crisis in 2008-2009 (Jia-Yuh Yeh, 2012; Chenyu Shany, 2012).

In current paper we are modelling on the basis of Lithuanian data and particularly focus on CDS data gathered from Bank of Lithuania. It is daily time series data for the period of 2007/01/01 - 2013/05/31. Thus in order to make the forecast model for CDS indicator the forecasting technique for times series will be implemented.

Exponential Smoothing is the method we choose to predict the future tendency of CDS indicator. It is quite simple methods to compare with VAR or DSGE modelling, which include many of indicators and parameters. Nevertheless we expect to find tendency in order to make some implications on the near future CDS market performance.

The computations were made with SAS computer package. The main results are presented in section 4.

\section{The results and the research findings}

The research results in this section will be provided in to aspects. Firstly the statistical data analysis will be presented (see section 4.1.), secondly the short model of CDS indicator will be explained (see section 4.2.).

\subsection{General statistics of the main economic indicators}

In previous sections it was mentioned that consumption is the main inspiration for economic prosperity. Thus public sectors' deficit/surplus indicator indeed reflects the important part of the whole consumption. Fig. 2 presents the dynamics of General government deficit/surplus as percentage of GDP in three Baltic States. General government involves central government, state government, local government, and social security funds. The data dynamics in Fig. 2 indicates almost the same level of deficit in both Lithuania and Latvia during the period of 2007-2012. While in Estonia had better situation, and did not reached the bottom that had previously mentioned countries, and moreover Estonia experienced recovery earlier - immediately after 2008.

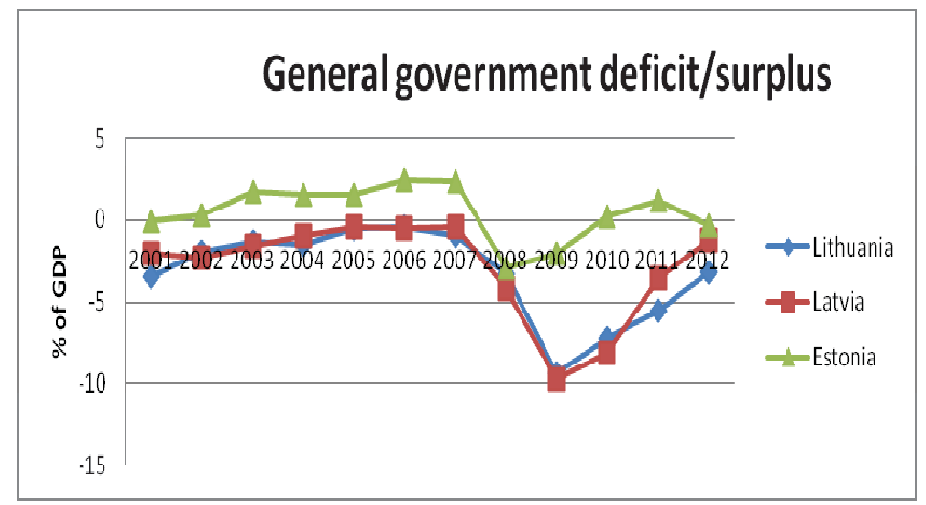

Figure 2. General government deficit/surplus as percentage of GDP (Calculations based on Eurostat data)

The role of the banking sector was emphasized in previous sections too. The importance of regulations of banking system, as well as the central bank policy regarding interest rate level is widely discussed in research discourse. The requirements for banks guaranteed asset, the banks liquidity are of extremely importance, for the survival purpose during deep recessions.

Fig. 3 presents the indicators of Liquidity ratio of the banking sector in Lithuania in the period of 2006 and 2012. Data dynamics of liquidity ratio during the analysed period ranged between 40-50 percent. The peak was reached in December of 2012.

Meanwhile deposits of customers gradually plunged since beginning of 2006 , and reached the lowest point in the 
end of 2008 (53.5 percent). Since then the deposits of customers were going upwards and the last date scored of 82.5 percent. It could be affected by both the decrease in total non-interbank loans and increase of deposit in bank, which suggests that customers trust the bank (Fig. 3).

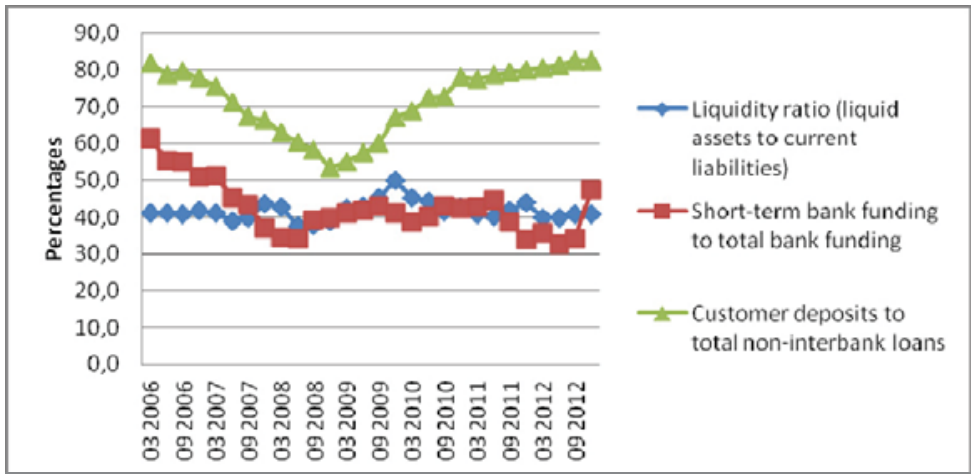

Figure 3. Liquidity ratio of the banking sector in Lithuania (Calculations based on Bank of Lithuania data)

The dynamics of the gross loan portfolio of EU countries is presented in fig. 4. The figure indicates the decline of this indicator in all presented countries. The highest peak of gross loan portfolio was in Latvia, and it had sharp slowdown comparing to other EU countries.

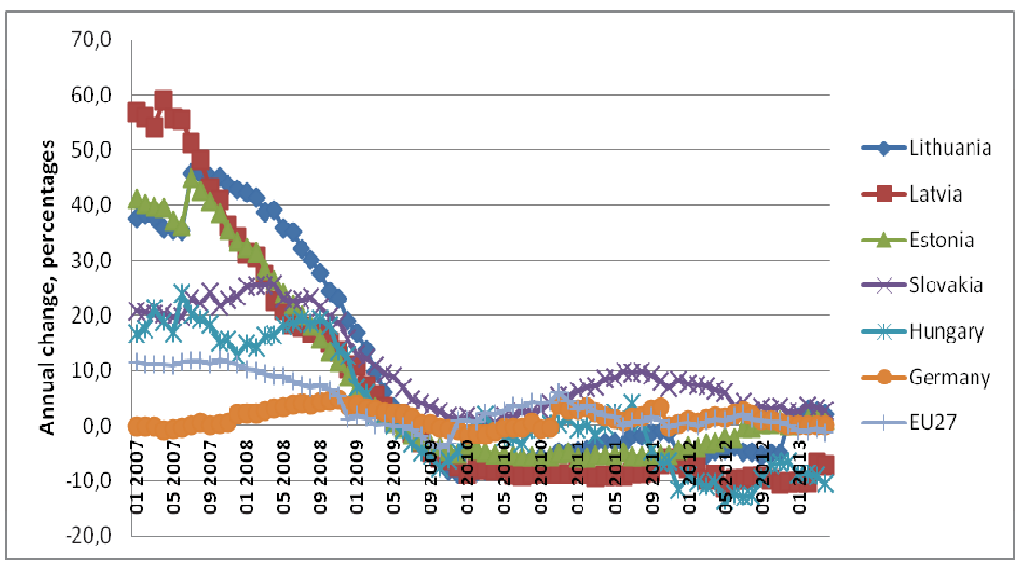

Figure 4. Dynamics of the gross loan portfolio of the EU countries (Calculations based on Bank of Lithuania data)

Thus statistical data in fig. 4 implicates that the highest percentage change in gross loan indicator was in all three Baltic States. There we observe the pro-cyclical features of economic behaviour of both, the public and the private sectors. The lowest indicator was for Germany which ranges around zero during the whole analysed period. It means that the anticyclical policy was implemented.

Still the effects of credit shocks are characterized by issued loans, and particular non -performing loans of banking sector. Fig. 5 outlines the dynamics of such indicator. As presented in the chart, percentage of business loans had sharp increased since the June of 2008, (score of 2.8 percent), the peak was reached in December of 2009 (score of 26.2). Still the effect of long term recession is indicated in fig. 5 - non-performing consumer loans reached the peak in June of 2011 (it lagged 1.5 year from business nonperforming loans rates). 


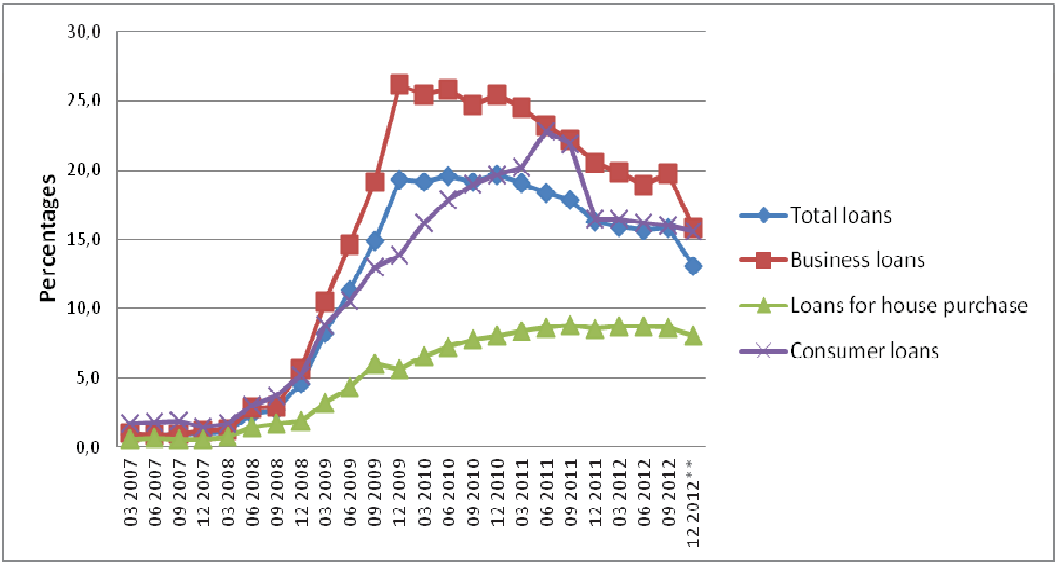

Figure 5. Non-performing loans of the banking sector in Lithuania (Calculations based on Bank of Lithuania data)

\subsection{Modelling the CDS indicator}

Referring to previous research made by Chenyu Shany (2012) indicated that CDS relates to reduction in debt contracting friction in terms of loosening covenants, in this section the Lithuanian CDS indicator will be analyzed. According to research results of Chenyu Shany (2012) "Strictness of net worth covenants decreases by 16.8\%, on average, after the inception of CDS trading". Thus in this section we will analyse times series data of CDS times series data in Lithuania.

The data in fig. 6 shows actual performance of CDS market in basic points. And it is obvious that's it is almost coincident with the difference between long-term Lithuanian government Eurobond and German government bond yields. The data in the fig. 6 refer to domestic risk premium indicators. Pilinkus, Svolka and Bartkus (2011) argue, that "Decreasing CDS's indicate diminishing risk of government loan default that foreign investors (government bond buyers) conceive".

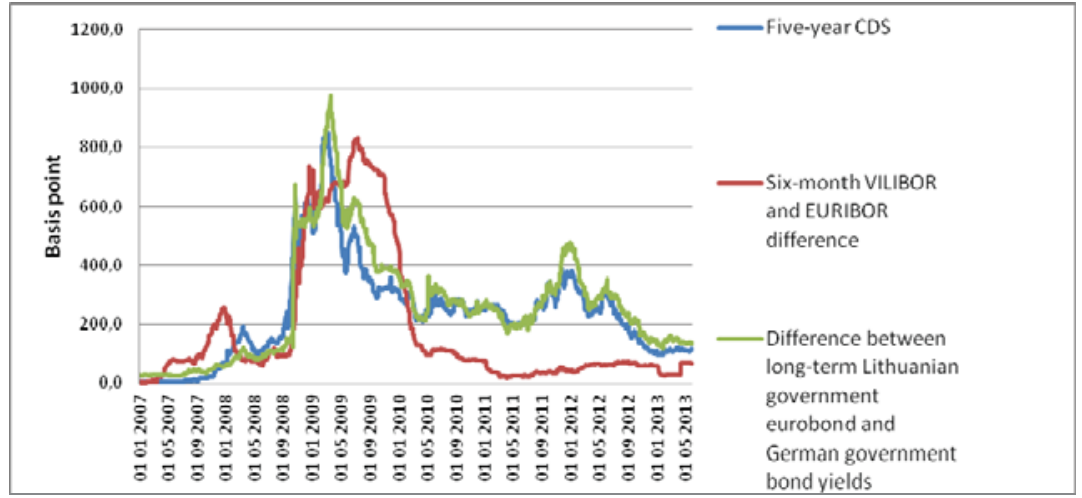

Figure 6. Dynamics of domestic risk premium indicators (Calculations based on Bank of Lithuania data)

CDS indicator Log Damped Trend Exponential Smoothing model (computations made with SAS computer package) is presented in the figure below (fig.7). The R-Square - 0.998, Mean Absolute Percent Error (MAPE) - 1.50715 indicates perfect fit, though the graph shows quite wide confidence interval, what implies wish for more reliable modelling. 


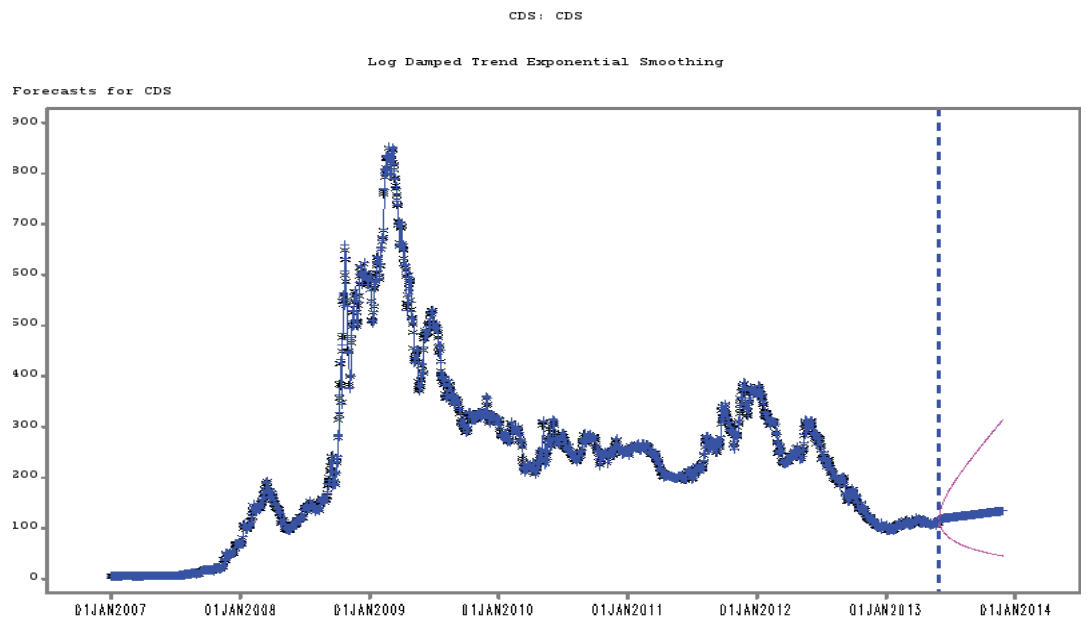

Figure 7. CDS Log Damped Trend Exponential Smoothing model

Overall the model implicates that forecasting for 6 month ahead the CDS indicator will have slightly upward tendency, not forgetting the assumption of all other factors to be stable. It is obvious that the methodology of such forecasting is based on one general assumption, that the best forecast for tomorrow is today, thus one should notice that trend in the model (fig.7) is based on the last data of analysed period, and it is possible that trend may reach at least average level of peak in 5-10 years when other factors to be constant. Thus if we would like to predict whether there will be a CDS indicator shock, we should stress that it unlikely to happen at least in 6 month prospect.

We acknowledge that to attempt predict economic crisis on the basis of one indicator may end in a failure. But we aim to extend model and to integrate more financial indicators in order to predict the future performance of economic cycles.

\section{The Concluding remarks}

The literature research indicated that low interest rates for borrowing, irresponsible banking sector lending policy, procyclical monetary policy are among the most common mentioned causes of recession, which in had enormous longlasting worldwide effects.

The model analysis in second section of this paper denotes that the usually applied forecasting techniques however have advantages and disadvantages too.

To summarize the statistical data analysis it should be beared in mind that despite of sufficient liquidity of Banks (Lithuanian case), huge risk and the uncertainty was not evaluated enough to secure future economy from the credit shock. Thus macroprudential issue in the monetary policies is of particular importance in order to overcome future irrational fluctuation of economies.

CDS Log Damped Trend Exponential Smoothing model analysis suggests that this indicator is slightly going up but the tendency for the coming 6 month upward indicates that the recovery will be slow. If to base on analysis of the CDS indicators, shock should be not expected in nearest future, being all other factors stable.

\section{References}

Abildgren, K. (2011). Financial Structures and the Real Effects of Credit-Supply Shocks in Denmark 1922-2011.ECB working paper NO 1460 / August 2012. Available: http://www.ecb.europa.eu/pub/pdf/scpwps/ecbwp1460.pdf

Almeida, H., Campello, M., Laranjeira B., and Weisbenner, S.. (2011). "Corporate Debt Maturity and the Real Effects of the 2007 Credit Crisis. Critical Finance Review 1: 3-58. [Online] Available: http://business.illinois.edu/weisbenn/Research/Papers/ CFR_DebtMaturity_Jan2012_3-58.pdf

Bank of Lithuania. [Online] Available: http://www.llbank.It/financial_stability_indicators_and_other_statistics

Bedock, N., and Stevanovic, D. (2012). Empirical study of credit shock transmission in a small open economy. Max Weber Programme, 
EUI Working Papers MWP 2012/02. [Online] Available: http://cadmus.eui.eu/bitstream/handle/1814/21741/ MWP_2012_02_Stevanovic.pdf?sequence=1

Carrillo, J., F'eve, P., Matheron, J. (2007). Monetary Policy Inertia or Persistent Shocks: A DSGE Analysis. [Online] Available: http://idei.fr/doc/wp/2007/monetary_policy.pdf

Chenyu Shany, S. (2012). Does CDS Trading Affect Debt Contracting? Evidence from Loan and Bond Covenants. The University of Hong Kong, October 31, 2012. Available at: http://www.fma.org/Shanghai/Papers/SusanShan_JMP_30.pdf

Chodorow-Reich, G. (2012). "The Employment Effects of Credit Market Disruptions: Firm-level Evidence from the 2008-2009 Financial Crisis." Unpublished Manuscript, available at: http://econgrads.berkeley.edu/gabecr/files/2011/05/The-Employment-Effects-ofCredit-Market-Disruptions4

Eurostat (2013). Available: http://epp.eurostat.ec.europa.eu/tgm/table.do?tab=table\&init=1\&plugin=1\&language=en\&pcode=tec00127

Fornari, F., \& Stracca, L. (2011). What does a financial shock do? First international evidence. Available: http://www.bis.org/events/bokbisimf2012/session2_what_does_a_financial_shock_do.pdf

Garcia, N.E. (2011). DSGE Macroeconomic Models: A Critique. Published in Economie Appliquée, N 1, January-March 2011, Paris. [Online] Available: http://www.itf.org.ar/pdf/documentos/82-2011.pdf

Gilchrist, S., \& Zakrajšek, E. Credit Supply Shocks and Economic Activity in a Financial Accelerator Model, April 10, 2012. [Online] Available: http://people.bu.edu/sgilchri/research/Russell_Sage_GZ_09Apr2012.pdf

Greenstone, M. and Mas, A. (2012 Nov.) Do Credit Market Shocks affect the Real Economy? Quasi-Experimental Evidence from the Great Recession and 'Normal' Economic Times. November, 2012. [Online] Available: http://economics.mit.edu/files/8709

Ivashina, V., \& Scharfstein, D. (2010). Bank lending during the financial crisis of 2008. Journal of financial Economics, 97(2010) 319338).

Jia-Yuh Yeh, A. (2012). Credit default swap spreads, fair-value spreads and interest rate dynamics. Journal of Credit Risk Volume 8/Number 4, Winter 2012/13 (53-129). [Online] Available: http://www.risk.net/digital_assets/6047/jcr_yeh_web.pdf

Maredza,A., \& Ikhide, S. (2013). Measuring the Impact of the Global Financial Crisis on Efficiency and Productivity of the Banking System in South Africa. Mediterranean Journal of Social Sciences Vol 4, No 6 (2013), DOI: 10.5901/mjss.2013.v4n6p553

Pesaran, M. H, Xu, T. (2013). Business Cycle Effects of Credit Shocks in a DSGE Model with Firm Defaults. [Online] Available: http://www.econ.cam.ac.uk/emeritus/pesaran/wp13/MacroCredit_PesaranXu-Feb-2013.pdf.

Pilinkus, D., Svolka, A., \& Bartkus, E.V. (2011).The Role of Currency Board Regime during Economic Crisis\. Inzinerine EkonomikaEngineering Economics, 2011, 22(4), 392-401.

Setterfield, M. (2011). Anticipations of the Crisis: On the Similarities between post-Keynesian Economics and Regulation Theory. [Online] Available: http://regulation.revues.org/9366

Wickens, M. (2012). How Useful are DSGE Macroeconomic Models for Forecasting? [Online] Available: http://www.iiw.unibonn.de/konstanz/2012/Paper_Wickens.pdf

Wieland, V., Cwik, T., Müller, G.J., Schmidt, S., and Wolters, M. (2012). A New Comparative Approach to Macroeconomic Modelling and Policy Analyses. [Online] Available: http://www.voxeu.org/sites/default/files/file/Wielandetal_120123.pdf 